\title{
Different effects of cortisol on pro- inflammatory gene expressions in LPS-, heat-killed E.coli-, or live E.coli-stimulated bovine endometrial epithelial cells
}

Luying Cui ${ }^{1,2+}$, Yali Wang ${ }^{1,2+}$, Heng Wang ${ }^{1,2}$, Junsheng Dong ${ }^{1,2}$, Zixiang Li $i^{1,2}$, Jun Li ${ }^{1,2}$, Chen Qian ${ }^{1,2}$ and Jianji Li $i^{1,2^{*}}$ (D)

\begin{abstract}
Background: Bacterial infections are common in postpartum dairy cows. Cortisol level has been observed to increase in dairy cows during peripartum period, and is associated with the endometrial innate immunity against pathogens like E.coli. However, the mechanism underlying how cortisol regulates E.coli-induced inflammatory response in bovine endometrial epithelial cells (BEEC) remains elusive.

Results: Cortisol decreased the expressions of IL1 $\beta, I L 6$, TNF- $\alpha$, IL8, and TLR4 mRNA in BEEC treated with LPS or heat-killed E.coli, but up-regulated these gene expressions in BEEC stimulated by live E.coli.

Conclusion: Cortisol exerted the anti-inflammatory action on LPS- or heat-killed E.coli-stimulated BEEC, but the proinflammatory action on live E.coli-induced BEEC.
\end{abstract}

Keywords: Endometritis, Bovine endometrial epithelial cells, Cortisol, Escherichia coli, Pro-inflammatory genes

\section{Background}

Endometritis is the inflammation of the endometrium which usually occurs in postpartum dairy cows. There are two main types of bovine endometritis, including clinical endometritis with purulent ( $>50 \%$ pus) discharge in uterine lumen between 20 and 33 days postpartum or mucopurulent (approximately 50\% pus and 50\% mucus) discharge after 26 to 33 days postpartum [1,2], and subclinical (cytological) endometritis, characterized by the abnormal proportion of polymorphonuclear (PMN) cells in endometrial cytology examination [1]. Endometritis causes infertility at the time the uterine infection is present and subfertility even after successful resolution of the disease, resulting in increased culling rate and great economic loss [2]. The most common cause of uterine infection is the

\footnotetext{
* Correspondence: yzjjli@163.com

${ }^{+}$Luying Cui and Yali Wang contributed equally to this work.

${ }^{1}$ College of Veterinary Medicine, Yangzhou University, 48 East Wenhui Rd, Yangzhou 225009, Jiangsu, China

${ }^{2}$ Jiangsu Co-innovation Center for the Prevention and Control of Important Animal Infectious Disease and Zoonoses, 48 East Wenhui Rd, Yangzhou 225009, Jiangsu, China
}

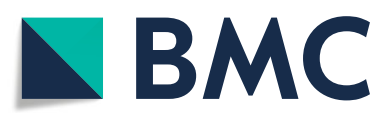

(c) The Author(s). 2020 Open Access This article is distributed under the terms of the Creative Commons Attribution 4.0 International License (http://creativecommons.org/licenses/by/4.0/), which permits unrestricted use, distribution, and reproduction in any medium, provided you give appropriate credit to the original author(s) and the source, provide a link to the Creative Commons license, and indicate if changes were made. The Creative Commons Public Domain Dedication waiver (http://creativecommons.org/publicdomain/zero/1.0/) applies to the data made available in this article, unless otherwise stated.

pathogenic microorganisms affecting productivity and fertility of cows. Infection of the endometrium with Escherichia coli (E.coli) precedes infection by Trueperella pyogenes and a range of anaerobic bacteria that include Fusobacterium, Prevotella and Bacteriodes species [3, 4].

Uterine defenses rely initially on classical innate immunity. The bovine endometrial epithelial cells (BEEC) are the first to make contact with potential pathogens that enter the uterus [5]. One of the critical mechanisms recognizing pathogens and their pathogen associated molecular patterns is Toll-like receptors [6]. It is the Toll-like receptor 4 (TLR4) that specifically recognizes the lipopolysaccharide (LPS), a structural component of the outer membrane of E.coli [7, 8]. The activation of TLR4 causes the recruitment of the signaling adaptor MyD88, resulting in the activation of the downstream NF- $\mathrm{KB}$ signaling pathways. These signaling cascades stimulate the expressions of pro-inflammatory mRNA transcripts in the endometrium, including the cytokines interleukin1 $\beta$ (IL1 $\beta$ ), IL6, tumor necrosis factor- $\alpha$ (TNF$\alpha)$ and the chemokine IL8 $[9,10]$. 
As a kind of glucocorticoids, cortisol is widely considered as an anti-inflammatory steroid hormone [11-13], which regulates all aspects of immune functions and inflammation [14]. The effects of glucocorticoids are described as inhibiting nuclear translocations and the functions of several pro-inflammatory transcription factors, then suppressing the syntheses of inflammatory mediators [15]. Increased level of endogenic cortisol was observed during parturition [16]. Previous study indicated that cortisol inhibited the inflammatory response in LPS-induced BEEC [17]. However, the relationship between cortisol and the endometritis caused by E.coli has not yet been clarified. The effect of cortisol on E.coli-stimulated BEEC is worthy of being investigated.

Here we reported the different effects of cortisol on the gene expressions of pro-inflammatory cytokines induced by E.coli or LPS. Quantitative PCR method was used to detect the expressions of IL1 $\beta$, IL6, TNF- $\alpha$, IL8, and TLR4 mRNA in BEEC co-treated with cortisol and LPS, heat-killed E.coli or live E.coli.

\section{Results}

\section{Cell viability}

Cell Counting Kit-8 (CCK-8) and trypan blue assay were used to evaluate the viability of BEEC after heat-killed or live E.coli challenge. As shown in Fig. 1a, no difference was observed in cell viability in BEEC treated with heatkilled E.coli $\left(1 \times 10^{8} \mathrm{CFU} / \mathrm{mL}\right)$ from 0 to $60 \mathrm{~h}$. Compared to the control group, the cell viability was not influenced by live E.coli $\left(1 \times 10^{6} \mathrm{CFU} / \mathrm{mL}\right)$ at $6 \mathrm{~h}$ (Fig. $\left.1 \mathrm{~b}\right)$.

\section{Pro-inflammatory genes and TLR4 mRNA expressions in BEEC co-treated with LPS and cortisol}

The effect of cortisol on the pro-inflammatory and TLR4 mRNA expressions in BEEC stimulated with LPS were shown in Fig. 2. Higher $(p<0.01)$ levels of LPSinduced IL1 $\beta$, IL6, TNF- $\alpha$, and IL 8 mRNA expressions were observed as compared with the control group at all time points, whereas the TLR4 mRNA increased $(p<$ 0.01 ) only at $6 \mathrm{~h}$ after challenge. Compared with E.coli treated group, cortisol $(5,15$, or $30 \mathrm{ng} / \mathrm{mL})$ decreased $(p<0.01)$ the mRNA expressions of TLR 4 at $6 \mathrm{~h}$, and the IL1 $\beta$, IL6, TNF- $\alpha$, and IL8 at most observed time points.

\section{Pro-inflammatory genes and TLR4 mRNA expressions in $B E E C$ co-treated with heat-killed E.coli and cortisol}

The results of IL1 $\beta$, IL6, TNF- $\alpha$, IL8, and TLR4 mRNA expressions in BEEC co-treated with heat-killed E.coli and cortisol were shown in Fig. 3. Exposure of cells to heat-killed E.coli upregulated $(p<0.01)$ the mRNA expressions of IL1 $\beta$, IL6, IL8, and TLR4 at all indicated time points, and TNF- $\alpha$ at 6 and $18 \mathrm{~h}$. Compared with E.coli treated group, cortisol $(5,15$, or $30 \mathrm{ng} / \mathrm{mL})$ treatment generally down-regulated $(p<0.05)$ these gene

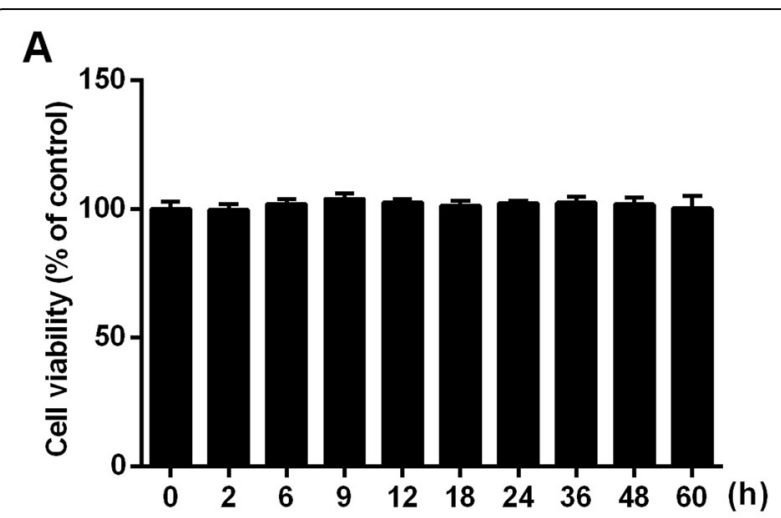

B

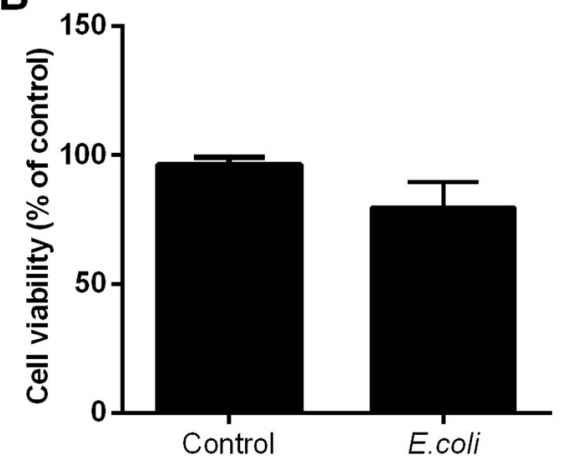

Fig. 1 The effect of heat-killed and live E.coli on bovine endometrial epithelium cell viability. a The cell viabilities of BEEC challenged by $1 \times 10^{8} \mathrm{CFU} / \mathrm{mL}$ heat-killed E.coli from 0 to $60 \mathrm{~h}$ were measured by CCK-8 assay. The data were presented as means $\pm \operatorname{SEM}(n=6) \cdot \mathbf{b}$ The cell viabilities of BEEC challenged by $1 \times 10^{6} \mathrm{CFU} / \mathrm{mL}$ live E.coli at $6 \mathrm{~h}$ were measured by trypan blue assay. The data were presented as means $\pm \operatorname{SEM}(n=3)$

expressions at 6 and $18 \mathrm{~h}$, and the IL1 $\beta$ and TLR4 mRNA at $2 \mathrm{~h}$.

Pro-inflammatory genes and TLR4 mRNA expressions in BEEC co-treated with live E.coli and cortisol

The results of IL1 $\beta$, IL6, IL8, TNF- $\alpha$, and TLR4 mRNA expressions were shown in Fig. 4. The mRNA expressions of IL1 $\beta$, IL6, IL8 and TNF- $\alpha$ increased $(p<0.01)$ by live E.coli challenge at all time points. The TLR4 mRNA in E.coli group decreased $(p<0.01)$ at 4 and $6 \mathrm{~h}$, and unchanged at $2 \mathrm{~h}$. Compared with E.coli treated group, co-treatment of cortisol and E.coli generally increased the mRNA expressions of IL1 $\beta$, IL6, IL8, and TNF- $\alpha$, which was most pronounced $(p<0.05)$ at $4 \mathrm{~h}$ by 5,15 and $30 \mathrm{ng} / \mathrm{mL}$ cortisol, at $2 \mathrm{~h}$ by $15 \mathrm{ng} / \mathrm{mL}$ cortisol, and at $6 \mathrm{~h}$ by $30 \mathrm{ng} / \mathrm{mL}$ cortisol. The mRNA levels of TLR4 in the co-treatment group were higher $(p<0.05)$ than the E.coli group at 2 and $4 \mathrm{~h}$.

\section{Discussion}

In this study, we demonstrated that cortisol inhibited the LPS- and heat-killed E.coli-induced expressions of 

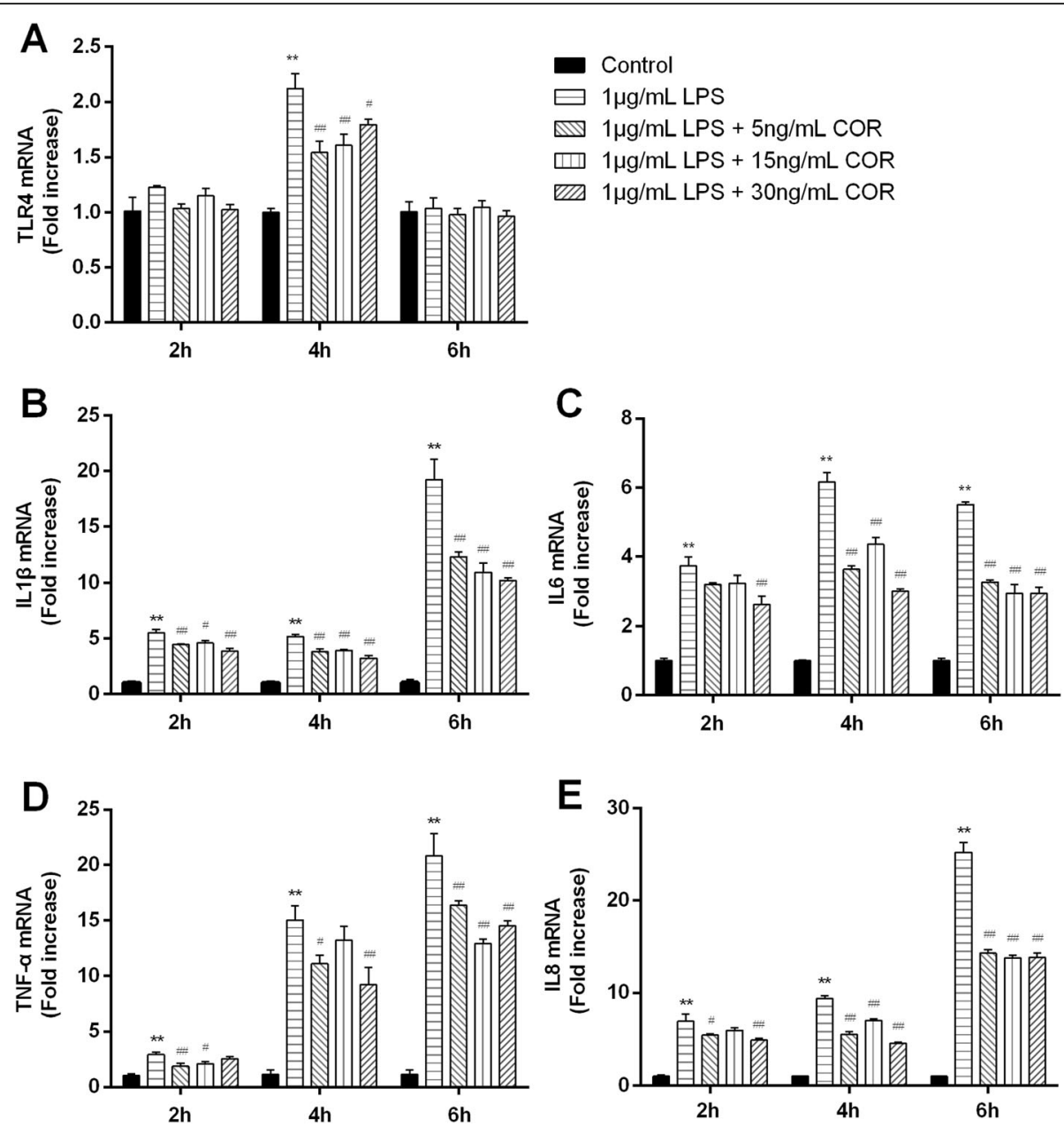

Fig. 2 Effects of cortisol on the mRNA expressions of TLR4 (a), IL1ß (b), IL6 (c), TNF-a (d) and IL8 (e) in LPS-stimulated bovine endometrial epithelial cells. Cells were co-treated with cortisol $(5,15$, or $30 \mathrm{ng} / \mathrm{mL})$ and LPS $(1 \mu \mathrm{g} / \mathrm{mL})$ for 2 , 6 , or $18 \mathrm{~h}$. RNA was isolated and analysed by $\mathrm{qPCR}$. The data were present as means \pm SEM $(n=3)$. COR, cortisol. ${ }^{* *} p<0.01$ vs the control group; ${ }^{\#} p<0.05$, ${ }^{\# \#} p<0.01$ vs the LPS group

pro-inflammatory genes (IL-1 $\beta$, IL-6, IL-8, TNF- $\alpha$, and TLR4) in BEEC. However, in cells challenged by live E.coli, we detected the reduced TLR4 mRNA expression and increased mRNA levels of IL-1 $\beta$, IL-6, IL-8, and TNF- $\alpha$. Co-treatment of cortisol and live E.coli further up-regulated the expressions of these pro-inflammatory genes.

Increased mRNA expressions of TLR4 have been reported in LPS-stimulated BEEC by Shen et al. [18], Herath et al. [9] and Dong et al. [17], and in heat-killed E.coli-stimulated BEEC by Chapwanya et al. [19]. Similarly, Yang et al. showed that heat-killed E.coli activated TLR4 receptor in HEK293 cells [20].. This concurs with our study, that LPS and heat-killed E.coli could upregulate TLR4 mRNA. Binding of LPS to TLR4 increases the secretion of inflammatory cytokines [21, 22]. IL1 $\beta$ and IL6 are classical pro-inflammatory cytokines. The activities of IL1 $\beta$ and IL6 are similar to TNF- $\alpha$, including the induction of pyrexia and the production of acute phase proteins [23]. IL8 is a chemokine that recruits immune cells such as neutrophils and lymphocytes, and stimulates the release of neutrophil granules [24]. Brauner et al. demonstrated that heat-killed E.coli induced the protein productions of IL- $1 \beta$, IL- 6 , IL- 8 , and TNF- $\alpha$ [25]. Similarly in our result, the gene expressions of IL$1 \beta$, IL-6, IL-8, and TNF- $\alpha$ increased following the stimulation with LPS or heat-killed E.coli.

In contrast with increased TLR4 mRNA expression induced by LPS or heat-killed E.coli, the live E.coli downregulated TLR4 expression. However, the levels of IL-1 $\beta$, IL-6, IL-8, and TNF- $\alpha$ mRNA increased after the live E.coli stimulation. Previous study indicated that the pathogenic mechanism of E.coli is complex. Some pathotypes of E.coli have a large repertoire of effectors that are translocated into host cells by the type III secretion system (T3SS) and affect host cell activities [26, 27]. T3SS can induce an early pro-inflammatory response through the activation of NF- $\mathrm{B}$ [28], resulting in the 

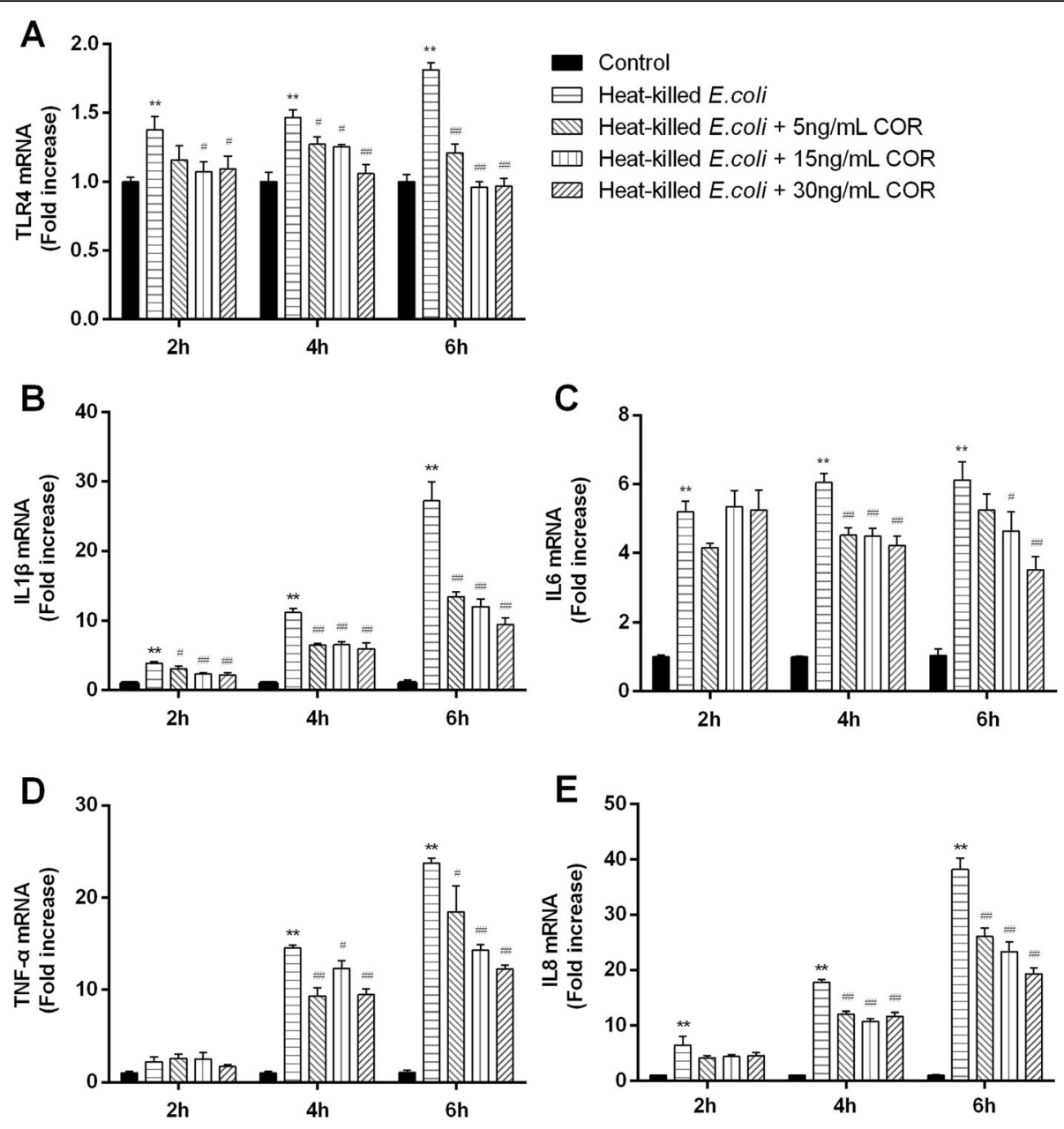

Fig. 3 Effects of cortisol on the mRNA expressions of TLR4 (a), IL1ß (b), IL6 (c), TNF-a (d) and IL8 (e) in heat-killed E.coli-stimulated bovine endometrial epithelial cells. Cells were co-treated with cortisol $(5,15$, or $30 \mathrm{ng} / \mathrm{mL})$ and heat-killed E.coli $\left(1 \times 10^{8} \mathrm{CFU} / \mathrm{mL}\right)$ for 2,6 , or $18 \mathrm{~h}$. RNA was isolated and analysed by qPCR. The data were present as means \pm SEM $(n=3)$. COR, cortisol. ${ }^{* *} p<0.01$ vs the control group; ${ }^{\#} p<0.05$, \#\# $p<0.01$ vs the heat-killed E.coli group

increased expression of pro-inflammatory genes. Another possibility was that several pathogenic Gramnegative bacteria have a modified lipid A, which is a part of LPS and enables the bacteria to evade TLR4-mediated immune surveillance [29]. This possibility was less likely because of the increased TLR4 expression in heat-killed E.coli group. Therefore, we speculated that the underlying mechanism of the increased expressions of inflammatory genes was not mediated by TLR4. We were unable to explain why the TLR4 gene expression decreased after the stimulation of live E.coli, which may require further investigation on TLR4 at posttranscriptional level and on the interaction between TLR4 and live E.coli.

It has been accepted that glucocorticoids induce anti-inflammatory effects by inhibiting the expressions of many pro-inflammatory genes [30] and the signal transduction of pattern recognition receptors [31]. According to the previous studies by our lab, cortisol inhibited the LPS-induced mRNA expressions of TLR4, IL-1 $\beta$, IL-6, IL-8, and TNF- $\alpha$ in BEEC [17]. In agreement with these reports, we found that cortisol exerted the classical antiinflammatory effects on BEEC induced with LPS or heatkilled E.coli. However, cortisol increased the levels of IL$1 \beta$, IL-6, IL-8, TNF- $\alpha$, and TLR4 mRNA in BEEC treated with live E.coli, exacerbating the pro-inflammatory effects. It has been reported that glucocorticoids have not only universally anti-inflammatory actions, but also proinflammatory effects in acute stress situations [32, 33]. The pro-inflammatory effects including increased expressions of chemokines, complement proteins, and cytokines [33], and inducing the secretion and activation of TLR signaling pathway [31, 32]. We hypothesized that the live E.coli stimulation may cause acute stress of cells, resulting 

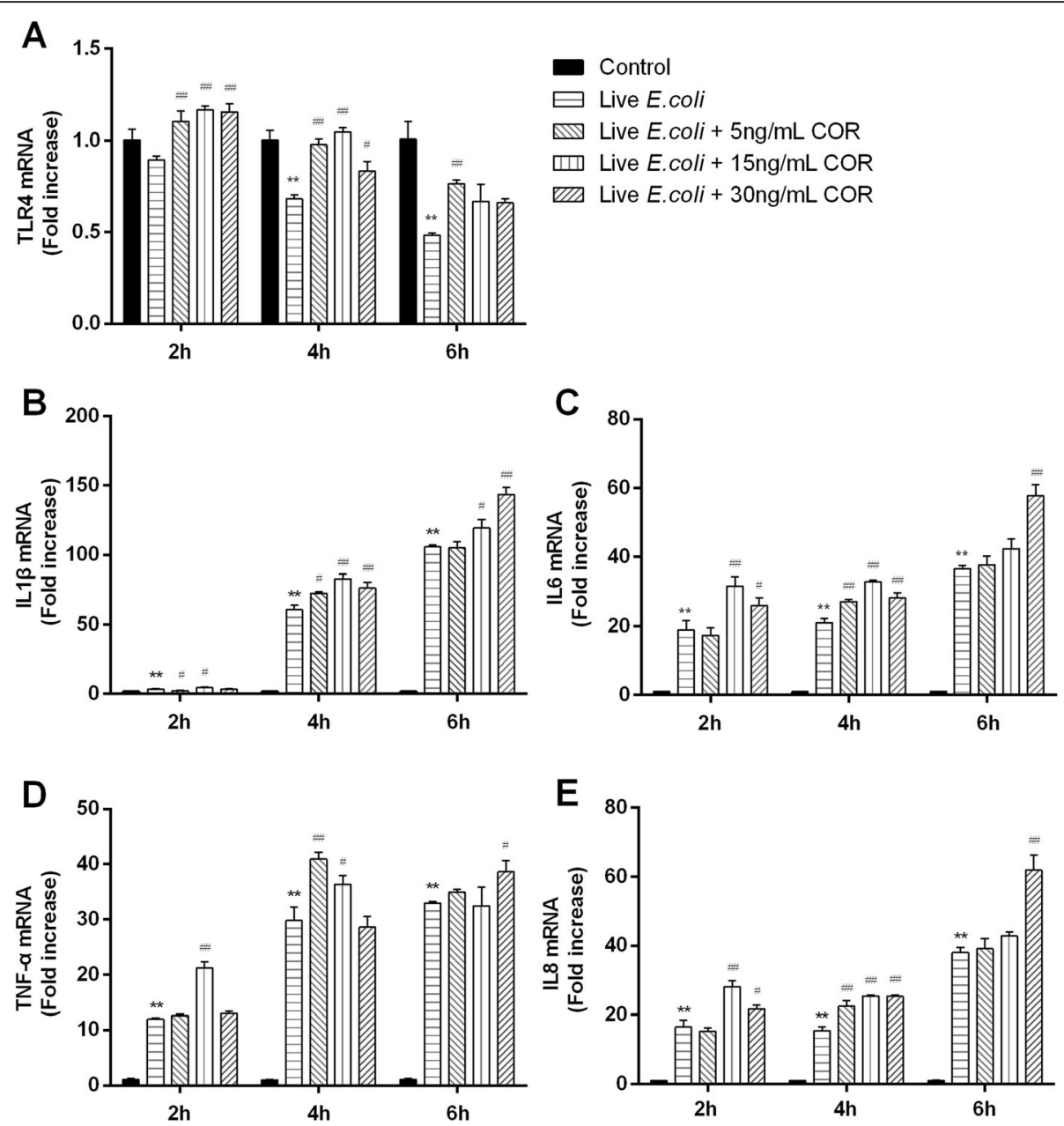

Fig. 4 Effects of cortisol on the mRNA expressions of TLR4 (a), IL1 $\beta$ (b), IL6 (c), TNF-a (d) and IL8 (e) in live E.coli-stimulated bovine endometrial epithelial cells. Cells were co-treated with cortisol $(5,15$, or $30 \mathrm{ng} / \mathrm{mL})$ and live E.coli $\left(1 \times 10^{6} \mathrm{CFU} / \mathrm{mL}\right)$ for 2,4 , or $6 \mathrm{~h}$. RNA was isolated and analysed by qPCR. The data were present as means \pm SEM $(n=3)$. COR, cortisol. ${ }^{* *} p<0.01$ vs the control group; ${ }^{\#} p<0.05$, \#\# $p<0.01$ vs the live E.coli group

in the pro-inflammatory effects of cortisol. There is a substantial space for further research to determine the condition and underlying mechanism of how the proinflammatory effects occur.

\section{Conclusion}

The present study demonstrated a two-side effect of cortisol in BEEC stimulated with LPS, heat-killed E.coli or live E.coli. Cortisol inhibited the LPS- or heat-killed E.coli-induced inflammatory response, but up-regulated the live E.coli-induced inflammatory response.

\section{Methods}

\section{Endometrial epithelium cell culture}

The cells were isolated as described from Dong et al. [17] and from Cui et al. [34]. Cattle with hoof disease or mastitis from experimental farm of Yangzhou University were sent to the local abattoir and were culled. Bovine uteri from postpubertal nonpregnant cattle with no evidence of genital disease or microbial infection were collected and kept on ice until further processing in the laboratory [10]. Briefly, the uterine horns were cut and digested with $0.1 \%$ protease from Streptomyces griseus (P5147, Sigma, USA) diluted in DMEM/F-12 (D8900, Sigma, USA) at $4{ }^{\circ} \mathrm{C}$ for $18 \mathrm{~h}$. Then the uterine horns were incised to facilitate scraping the endometrium. The scraped materials were washed, collected and centrifuged at $1000 \times g$ for $5 \mathrm{~min}$. The cells were resuspended in DMEM/F-12 containing $15 \%$ fetal bovine serum (FBS, Gibco, USA) and $50 \mathrm{U} /$ $\mathrm{mL}$ of penicillin/streptomycin. These cells were seeded in $25 \mathrm{~cm}^{2}$ flasks and cultured at $37^{\circ} \mathrm{C}$ containing $5 \% \mathrm{CO}_{2}$. The medium was changed when the cells reached $90 \%$ confluence. The purification of 
BEEC was confirmed to be above $99 \%$ by detecting CK-18 using immunohistochemistry.

\section{Bacteria}

E.coli $\mathrm{O} 55$ was obtained and isolated from a cow with endometritis (purulent uterine discharge) at experimental farm of Yangzhou University. The strain was routinely cultured overnight $\left(37^{\circ} \mathrm{C}, 120 \mathrm{rpm}\right)$ in nutrient $\mathrm{LB}$ broth (L3022, Sigma, USA), and the bacterial fluid was pipetted into sterile $\mathrm{LB}$ for incubating $\left(37^{\circ} \mathrm{C}, 120 \mathrm{rpm}\right)$ until to an optical density (OD $600 \mathrm{~nm}$ ) of 0.6 to have a final density to $4 \times 10^{8} \pm 1 \times 10^{8} \mathrm{CFU} / \mathrm{mL}$. Both active and heat-inactive E.coli were used in this study. For live E.coli, the bacterial suspension was centrifuged at $4000 \times g$ for $10 \mathrm{~min}$ and followed twice further washes with PBS, then resuspended in DMEM/F-12 to a dose of $1 \times 10^{6} \mathrm{CFU} / \mathrm{mL}$. To inactive bacteria, the bacterial suspension was heat killed for $60 \mathrm{~min}$ at $70^{\circ} \mathrm{C}$ after washed with $\mathrm{PBS}$ as described. Then it was centrifuged at $4000 \times g$ for $10 \mathrm{~min}$ and resuspended in DMEM/F-12 to have a final inoculum corresponding to $1 \times 10^{8} \mathrm{CFU} / \mathrm{mL}$. The doses of active and heat-inactive E.coli were selected based on a preliminary study and on studies of Korzekwa et al. [35] and Brauner et al. [25], respectively.

\section{Experiment design and treatments}

To evaluate the impact of cortisol on the inflammatory response of BEEC induced by E.coli or LPS, the cells plated on 6-well plates at a density of $1 \times 10^{6}$ cells per well were challenged with $1 \times 10^{6} \mathrm{CFU} / \mathrm{mL}$ live E.coli, $1 \times 10^{8} \mathrm{CFU} / \mathrm{mL}$ heat-killed E.coli, or $1 \mu \mathrm{g} / \mathrm{mL}$ LPS in the control medium or the medium containing cortisol (H0888, Sigma, USA). The concentrations of cortisol from $5 \sim 30 \mathrm{ng} / \mathrm{mL}$ were within the physiological levels in cows. The selection of 5,15 , and $30 \mathrm{ng} / \mathrm{mL}$ cortisol was based on a previous report of our lab [17]. For detecting the gene expressions of the cytokines, the cells were collected at 2, 4, and $6 \mathrm{~h}$ after live E.coli challenge or 2, 6, and $18 \mathrm{~h}$ after heat-killed E.coli or LPS stimulation.

\section{Cell viability assay}

The previous study in our lab demonstrated that 5, 15, and $30 \mathrm{ng} / \mathrm{mL}$ cortisol had no effect on BEEC viability [17]. To determine the effect of heat-killed E.coli on cell viability, the Cell Counting Kit-8 (CCK-8) obtained from Dojindo Molecular Technologies, Inc. (Kumamoto, Japan) was used. The cells were plated on 96-well plates at a density of $1 \times 10^{3}$ cells per well and grown to $80 \%$ confluence in a $37^{\circ} \mathrm{C}, 5 \% \mathrm{CO}_{2}$ incubator. Then the cells were treated with $1 \times 10^{8} \mathrm{CFU} / \mathrm{mL}$ heat-killed E.coli for $0,2,6,9,12,16,18,24,48$, and $60 \mathrm{~h}$, followed by the addition of CCK-8 to each well. After incubation for $2 \mathrm{~h}$ at $37^{\circ} \mathrm{C}$, the optical density (OD $450 \mathrm{~nm}$ ) was detected with a microplate reader (Tecan, Austria).

The effect of live E.coli on cell viability was evaluated by trypan blue assay (C0011, Beyotime, China). The cells were incubated in the 6 -well plates $\left(1 \times 10^{6}\right.$ cells per well) and grown to $80 \%$ confluence. After treatment with $1 \times 10^{6} \mathrm{CFU} / \mathrm{mL}$ E.coli for $6 \mathrm{~h}$, the cell suspension was mixed with trypsin blue according to the manufacturer's protocol. Cells were counted using a cytometer (TC10, Bio-Rad).

\section{RNA extraction and quantitative PCR}

After treatment, cells were washed with $1 \mathrm{~mL}$ of PBS. Total RNA was extracted using the TRIzol reagent $(15,596,018$, Thermo, USA) according to the manufacturer's protocol. The extracted RNA was quantified using a Nanodrop 2000 spectrophotometer (Thermo, USA). Total RNA $(1 \mu \mathrm{g})$ was reverse transcribed into cDNA with the PrimerScript $\mathrm{RT}$ regent Kit gDNA Eraser (DRR047A, Takara, Japan). Real-time PCR was carried out by using SYBR Premix Ex $\mathrm{Taq}^{\text {TM }}$ II (RR820A, TaKaRa, Japan) on the CFX 96 Real-Time PCR Detection System (BIO-RAD, USA) as previously described [34]. The $2^{-\Delta \Delta C t}$ method was used to analyze the relative gene expression. The $\beta$-actin was used as the internal control. The sequences of the primers were shown in Table 1. The PCR experiments were performed in triplicate.

\section{Statistical analysis}

Data analysis was performed using IBM SPSS Statistics 21.0 (IBM, NY, USA). All data were expressed as the means \pm standard error (SEM). The significance of differences between groups was evaluated by one-way ANOVA, followed by Dunnett's test. Significance was

Table 1 The list of primer sequences used for amplification of qPCR

\begin{tabular}{|c|c|c|}
\hline Gene & Primer sequence $\left(5^{\prime} \rightarrow 3^{\prime}\right)$ & Accession number \\
\hline \multirow[t]{2}{*}{$\overline{\beta-A c t i n}$} & F: CATCACCATCGGCAATGAGC & \multirow[t]{2}{*}{ NM_173979.3 } \\
\hline & R: AGCACCGTGTTGGCGTAGAG & \\
\hline \multirow[t]{2}{*}{ TLR4 } & F: GCTCTGCCTTCACTACAGGGACT & \multirow[t]{2}{*}{ NM_174198.6 } \\
\hline & R: CTGGGACACCACGACAATAACC & \\
\hline \multirow[t]{2}{*}{ IL $1 \beta$} & F: TGATGACCCTAAACAGATGAAGAGC & \multirow[t]{2}{*}{ NM_174093.1 } \\
\hline & R: CCACGATGACCGACACCACCT & \\
\hline \multirow[t]{2}{*}{ IL6 } & F: TGAAAGCAGCAAGGAGACACT & \multirow[t]{2}{*}{ NM_173923.2 } \\
\hline & R: TGATTGAACCCAGATTGGAAGC & \\
\hline \multirow[t]{2}{*}{ TNF-a } & F: CCCTTGTTCCTCACCCAC & \multirow[t]{2}{*}{ NM_173966.2 } \\
\hline & R: CTCGGCATAGTCCAGGTAG & \\
\hline \multirow[t]{2}{*}{ IL8 } & F: TTCCTCAGTAAAGATGCCAATG & \multirow[t]{2}{*}{ NM_173925.2 } \\
\hline & R: TGACAACCCTACACCAGACCCA & \\
\hline
\end{tabular}


attributed when a two-sided $p$-value was less than 0.05 . Each experiment was repeated three times.

\section{Abbreviations}

BEEC: Bovine endometrial epithelial cells; CCK-8: Cell Counting Kit-8; cDNA: Complementary DNA; DMEM/F-12: Dulbeccos's Modified Eagle Media/ Nutrient Mixture F-12; E.coli: Escherichia coli; FBS: Fetal bovine serum: LB: Luria-Bertani; LPS: Lipopolysaccharide; qPCR: Quantitative polymerase chain reaction; T3SS: Type III secretion system

\section{Acknowledgements}

Not applicable.

\section{Authors' contributions}

LC drafted the manuscript, performed qPCR. YW participated in cell culture and performed $\mathrm{qPCR}$. HW participated in data collection and analysis. ZL and JD participated sample collection and cell culture. JL participated in bacteria culture. CQ participated in the data collection and analysis. JJ (Jianji Li) designed the present study. All authors have read and approved the manuscript.

\section{Funding}

This work was supported by the National Natural Science Foundation of China (31672614, 31802253); the China Postdoctoral Science Foundation (2018 M632398); the Natural Science Foundation of the Jiangsu Higher Education Institutions of China (17KJB230007); the Natural Science Foundation of Jiangsu Province (BK20160062); the Outstanding Young Backbone Teacher Foundation of Yangzhou University; the China Scholarship Council (201908320077); and the Priority Academic Program Development of Jiangsu Higher Education Institutions (PAPD); the Topnotch Academic Programs Project of Jiangsu Higher Education Institutions (TAPP). The funders had no role in study design, data collection, analysis and interpretation, decision to publish, or preparation of the manuscript.

\section{Availability of data and materials}

The datasets used and analysed during the current study available from the corresponding author on reasonable request.

\section{Ethics approval and consent to participate}

This study was conducted according to the guidelines of College of Veterinary Medicine, Yangzhou University. This study was approved by Yangzhou University.

\section{Consent for publication}

Not applicable.

\section{Competing interests}

The authors declare that they have no competing interests.

Received: 17 October 2019 Accepted: 3 January 2020

Published online: 09 January 2020

\section{References}

1. Gobikrushanth M, Salehi R, Ambrose DJ, Colazo MG. Categorization of endometritis and its association with ovarian follicular growth and ovulation, reproductive performance, dry matter intake, and milk yield in dairy cattle. Theriogenology. 2016;86(7):1842-9.

2. LeBlanc SJ, Duffield TF, Leslie KE, Bateman KG, Keefe GP, Walton JS, Johnson $\mathrm{WH}$. Defining and diagnosing postpartum clinical endometritis and its impact on reproductive performance in dairy cows. J Dairy Sci. 2002;85(9): 2223-36.

3. Sheldon IM, Cronin JG, Healey GD, Gabler C, Heuwieser W, Streyl D, Bromfield JJ, Miyamoto A, Fergani C, Dobson H. Innate immunity and inflammation of the bovine female reproductive tract in health and disease. Reproduction. 2014;148(3):R41-51.

4. Sheldon IM, Price SB, Cronin J, Gilbert RO, Gadsby JE. Mechanisms of infertility associated with clinical and subclinical Endometritis in high producing dairy cattle. Reprod Domest Anim. 2009;44:1-9.

5. Azawi Ol. Postpartum uterine infection in cattle. Anim Reprod Sci. 2008; 105(3-4):187-208
6. Davies D, Meade KG, Herath S, Eckersall PD, Gonzalez D, White JO, Conlan RS, O'Farrelly C, Sheldon IM. Toll-like receptor and antimicrobial peptide expression in the bovine endometrium. Reprod Biol Endocrinol. 2008;6:53.

7. Newton K, Dixit VM. Signaling in innate immunity and inflammation. Cold Spring Harb Perspect Biol. 2012;4:3.

8. Moresco EM, LaVine D, Beutler B. Toll-like receptors. Curr Biol. 2011;21(13): R488-93.

9. Herath S, Fischer DP, Werling D, Williams EJ, Lilly ST, Dobson H, Bryant CE, Sheldon IM. Expression and function of toll-like receptor 4 in the endometrial cells of the uterus. Endocrinology. 2006;147(1):562-70.

10. Cronin JG, Turner ML, Goetze L, Bryant CE, Sheldon IM. Toll-like receptor 4 and MYD88-dependent signaling mechanisms of the innate immune system are essential for the response to lipopolysaccharide by epithelial and stromal cells of the bovine endometrium. Biol Reprod. 2012;86(2):51

11. Straub RH, Cutolo M. Glucocorticoids and chronic inflammation. Rheumatology (Oxford). 2016;55(suppl 2):ii6-ii14.

12. Busada JT, Cidlowski JA. Mechanisms of glucocorticoid action during development. Curr Top Dev Biol. 2017:125:147-70.

13. Barnes PJ. Anti-inflammatory actions of glucocorticoids: molecular mechanisms. Clin Sci (Lond). 1998;94(6):557-72.

14. Hapgood JP, Avenant C, Moliki JM. Glucocorticoid-independent modulation of GR activity: implications for immunotherapy. Pharmacol Ther. 2016;165:93-113.

15. Stahn C, Lowenberg M, Hommes DW, Buttgereit F. Molecular mechanisms of glucocorticoid action and selective glucocorticoid receptor agonists. Mol Cell Endocrinol. 2007;275(1-2):71-8.

16. Kindahl $H$, Kornmatitsuk $B$, Gustafsson $H$. The cow in endocrine focus before and after calving. Reprod Domest Anim. 2004;39(4):217-21.

17. Dong J, Qu Y, Li J, Cui L, Wang Y, Lin J, Wang H. Cortisol inhibits NF-kappaB and MAPK pathways in LPS activated bovine endometrial epithelial cells. Int Immunopharmacol. 2018;56:71-7.

18. Shen Y, Liu B, Mao W, Gao R, Feng S, Qian Y, Wu J, Zhang S, Gao L, Fu C, et al. PGE2 downregulates LPS-induced inflammatory responses via the TLR4-NF-kappaB signaling pathway in bovine endometrial epithelial cells. Prostaglandins Leukot Essent Fatty Acids. 2018;129:25-31.

19. Chapwanya A, Meade KG, Doherty ML, Callanan JJ, O'Farrelly C. Endometrial epithelial cells are potent producers of tracheal antimicrobial peptide and serum amyloid A3 gene expression in response to $\mathrm{E}$. coli stimulation. Vet Immunol Immunopathol. 2013;151(1-2):157-62.

20. Yang W, Zerbe H, Petzl W, Brunner RM, Günther J, Draing C, von Aulock S, Schuberth HJ, Seyfert HM. Bovine TLR2 and TLR4 properly transduce signals from Staphylococcus aureus and E. coli, but $\mathrm{S}$. aureus fails to both activate NF-kB in mammary epithelial cells and to quickly induce TNFa and interleukin-8 (CXCL8) expression in the udder. Mol Immunol. 2008;45(5): 1385-97.

21. Lyu A, Chen JJ, Wang HC, Yu XH, Zhang ZC, Gong P, Jiang LS, Liu FH. Punicalagin protects bovine endometrial epithelial cells against lipopolysaccharide-induced inflammatory injury. J Zhejiang Univ Sci B. 2017; 18(6):481-91.

22. Lim KH, Staudt LM. Toll-like receptor signaling. Cold Spring Harb Perspect Biol. 2013;5(1):a011247.

23. Borish LC, Steinke JW. 2. Cytokines and chemokines. J Allergy Clin Immunol. 2003:111(2 Suppl):S460-75.

24. Sikora J, Smycz-Kubanska M, Mielczarek-Palacz A, Kondera-Anasz Z. Abnormal peritoneal regulation of chemokine activation-The role of IL-8 in pathogenesis of endometriosis. Am J Reprod Immunol. 2017;77:4.

25. Brauner A, Soderhall M, Jacobson SH, Lundahl J, Andersson U, Andersson J. Escherichia coli-induced expression of IL-1 alpha, IL-1 beta, IL-6 and IL-8 in normal human renal tubular epithelial cells. Clin Exp Immunol. 2001;124(3): 423-8.

26. Croxen MA, Finlay BB. Molecular mechanisms of Escherichia coli pathogenicity. Nat Rev Microbiol. 2010;8(1):26-38.

27. Clements A, Young JC, Constantinou N, Frankel G. Infection strategies of enteric pathogenic Escherichia coli. Gut Microbes. 2012;3(2):71-87.

28. Pallett MA, Berger CN, Pearson JS, Hartland EL, Frankel G. The type III secretion effector NleF of enteropathogenic Escherichia coli activates NFkappaB early during infection. Infect Immun. 2014;82(11):4878-88.

29. Kayagaki N, Wong MT, Stowe IB, Ramani SR, Gonzalez LC, Akashi-Takamura S, Miyake K, Zhang J, Lee WP, Muszynski A, et al. Noncanonical inflammasome activation by intracellular LPS independent of TLR4. Science. 2013;341(6151):1246-9. 
30. Barnes PJ. Mechanisms and resistance in glucocorticoid control of inflammation. J Steroid Biochem Mol Biol. 2010;120(2-3):76-85.

31. Chinenov Y, Rogatsky I. Glucocorticoids and the innate immune system: crosstalk with the toll-like receptor signaling network. Mol Cell Endocrinol. 2007;275(1-2):30-42.

32. Cruz-Topete D, Cidlowski JA. One hormone, two actions: anti- and proinflammatory effects of glucocorticoids. Neuroimmunomodulation. 2015; 22(1-2):20-32.

33. Sorrells SF, Sapolsky RM. An inflammatory review of glucocorticoid actions in the CNS. Brain Behav Immun. 2007;21(3):259-72.

34. Cui L, Wang H, Lin J, Wang Y, Dong J, Li J, Li J. Progesterone inhibits inflammatory response in E.coli- or LPS-Stimulated bovine endometrial epithelial cells by NF-KB and MAPK pathways. Dev Comp Immunol. 2020; 105:103568. https://doi.org/10.1016/j.dci.2019.103568.

35. Korzekwa AJ, Lupicka M, Socha BM, Szczepanska AA, Piotrowicz E, Baranski W. In vitro cow uterine response to Escherichia coli, leukotrienes and cytokines. Vet Immunol Immunopathol. 2016;182:59-62.

\section{Publisher's Note}

Springer Nature remains neutral with regard to jurisdictional claims in published maps and institutional affiliations.

Ready to submit your research? Choose BMC and benefit from:

- fast, convenient online submission

- thorough peer review by experienced researchers in your field

- rapid publication on acceptance

- support for research data, including large and complex data types

- gold Open Access which fosters wider collaboration and increased citations

- maximum visibility for your research: over $100 \mathrm{M}$ website views per year

At $\mathrm{BMC}$, research is always in progress.

Learn more biomedcentral.com/submissions 